\title{
STIMULATED RECALL IN EXPLORING THE CONSTRAINTS OF REFLECTIVE THINKING
}

\author{
Kálmán Sántha \\ Kodolányi János University of Applied Sciences, Székesfehérvár, Hungary \\ E-mail: skalman@uranos.kodolanyi.hu
}

\begin{abstract}
The study focuses on exploring the reflective constraints of a pedagogue in the framework of reflective thinking. By applying the qualitative technique of stimulated recall, video-taped lesson analysis and commentaries on real life classes it shows the factors restricting reflective thinking. The participant in the study was a secondary school teacher of mathematics pursuing his teaching career for nine years. The pedagogue's three lessons were recorded with the help of a technical expert. The recording of the lessons took place on three consecutive days, in the same class covering the same topic. The research was conducted by triangulation. Text analysis was carried out using the MAXQDA software by combining deductive and inductive coding processes. The findings show that emotions attached to teaching, lack of pedagogical knowledge and school context restricted the reflective thinking of the pedagogue. The results justified that developing reflective thinking contributes to making teacherly activities more effective and reflection can also further differentiate pedagogical knowledge. The results of the research might be applied in teacher training and further education. In addition the qualitative method called stimulated recall might also be relevant for researchers dealing with qualitative methodology.
\end{abstract}

Key words: reflective thinking, stimulated recall, text analysis.

\section{Introduction}

When examining the process of becoming a teacher and the professionalisation of the teaching activity reflective thinking deserves special emphasis. It is an important question for education politicians, teacher trainers, practising teachers and for the whole society who and under what conditions can start a teaching career. What are the levels of professional achievement in the teaching profession? What should competence-based teacher training be like? There is an agreement among professionals that creating and developing reflective thinking is necessary in the system of teacher training since it can increase the effectiveness of teaching. Throughout a training and a further education training would-be and practising teachers can learn to reflect on their own activities, can acquire methods and techniques with the help of which they can even analyse their own work by themselves.

The present study has a twofold aim: first, it emphasises the role of reflective thinking in the teaching activity; second, with the help of the qualitative technique of stimulated recall (video-taped lesson analysis) it illustrates the presence of reflective constraints in the teaching activity. Thanks to modern technology we can receive a comprehensive view of the interaction of complicated elements determining the teaching process.

There are two viewpoints in connection with the novelty of the research. On one hand the study gives a detailed description about the applicability of the qualitative method called stimulated recall in pedagogical researches. In this way it draws the attention to a method that is able to help reflec- 
tion. On the other hand it lays emphasis on the necessity of the analysis of reflective constraints while taking a complex examination.

\section{Theoretical Background}

Reflective thinking can cover all the elements of the teaching activity, and it also facilitates analysing, diagnosing and developing activities. Reflectivity already appeared in John Dewey's work (Dewey, 1933), a significant representative of pragmatism; however, the examination of teachers' reflective approach appeared in the USA in the 1980s; the introduction of the term "reflective teacher" into research on pedagogues" thinking can be attributed to Donald Schön. Schön studied the professional activities of people reflecting. In his book titled The Reflective Practitioner he described how intellectuals in different professions think during their problem-solving activities, then a couple of years later in another book called Educating the Reflective Practitioner he scrutinized how reflective professional practice can be taught to students (Schön, 1983, 1987).

Reflection can be interpreted as a dialogue between the situation and the reflecting person (e.g. the pedagogue) (Schön, 1983). According to a position similar to this one reflection means the systematic consideration of the effects of teaching activities on other people (e.g. students) and the teacher him/herself (Falus \& Kimmel, 2003). Szivák (2003) talks about collegial reflection when pedagogues' professional dialogues contribute to the development of teaching activities. During collegial reflection, it refers to past events most frequently, the reason for which is that unprocessed negative experience (if any) on earlier classes should not project themselves on future activities. The process can be regarded as the exploration and analysis of all the experience gained through teaching; therefore, it can also be used as a common interpretation of both positive and negative effects.

Today we have information on the emergence of reflective thinking in teaching (Atkinson \& Claxton, 2000), the spiral shape and circular process of reflection (Jank \& Meyer, 2002; Schratz, 1998) and on the factors restricting reflection (Kimmel, 2006). Furthermore, methods applicable for examining reflective thinking like stimulated recall, cognitive mapping and reflective journal are also well-known.

However, reflective thinking cannot be discussed without examining the beliefs influencing teaching activities. In the process of becoming a teacher a determining role can be attributed to the beliefs that can be described besides profession, identity, competences, activities and the environment (Korthagen, 2004). Beliefs are presuppositions about the world, assumptions that their creators consider to be true, but behind these assumptions this is not necessarily the real truth that lies; they influence how other people are judged, they are cognitive in their nature, they are hidden and explorable. Beliefs appear as filters in the activities of pedagogues (Falus, 2001; Richardson, 1996). The reflection of one's own convictions, ideas and expectations requires the often implicit and unconscious theories to become explicit and conscious. These subjective theories may oppose other subjective ideas or objective scientific theses that can overwrite and alter one's own ideas (Lohmann, 2003). Teachers possess a by and large coherent view, which they exploit in their teaching practice. Their ideas can be originated from their own life experience, their individual learning experience from their own student years, their experience from their formal training, and their own teaching practice (Falus, 2001).

\section{Methodology of Research}

\section{Sample of Research}

The participant in the study was a secondary school teacher of mathematics pursuing his teaching career for nine years, who was selected by the so called comfort method. In this case the person that can be easily reached by the researcher takes part in the research but comfort sampling can be problematic in qualitative studies since teachers were reluctant to participate in an examination including video-taped stimulated recall due to its specialities and time-consuming nature. The study concentrates on exploring individual and situation-dependent factors and reflective constraints. Because of its qualitative nature representativity is not a criterion to be fulfilled in this research project. 
In every phase of the research the aim was to build an appropriate professional and collegial rapport between the researcher and the participant, which excluded deception and misleading. Before the examination it was necessary to inform the participant about the aims of the research and about the process of stimulated recall. Taking into consideration the specialities of the research methodology applied the research was carried out with the consent of the school management and the pedagogue, which guaranteed anonymity for the participant.

\section{Instrument and Procedures} 2007):

While applying the technique of stimulated recall the following phases were completed (Sántha,

1. The lesson was recorded on videotape. The pedagogue's three lessons were recorded with the help of a technical expert. The recording of the lessons took place on three consecutive days, in the same class covering the same topic, which made it possible to analyse the teacherly activities in its process. During the recording the pedagogue's activities created the main criteria of investigation; the camera followed the movements of the teacher in the classroom. Using multiple cameras could have provided more information, but their accomplishment was prevented by technical and financial obstacles. Before the research even the technical expert had to be informed about the most important aspects of the investigation so that all the important moments of the lessons could be recorded. Taking into consideration the fact that every investigation is an intrusion into the life of the people involved reality cannot be fully explored (e.g. the class and the teachers behave differently if they are aware of the fact that the class is being recorded); therefore, the recording of several classes probably reduced the distorting factors as both the pedagogue and the students could become accustomed to the presence of the camera. The other problem could be that for the technical expert and for the researcher not the same classroom activity could bring important information (see subjectivity, problem of perception). To overcome this problem even the researcher could have recorded the lessons. This option, however, could not be pursued: on the one hand, the presence of the technical expert guaranteed the quality of the recording, on the other hand, while recording the researcher had the opportunity to observe and record the events he found important. These notes provided extra information for a better understanding of the cause-and-effect relationships of teacherly activities.

2. Watching the recordings together with the pedagogue, which happened right after the recording itself (after a 10-15-minute break minimally, or on the day of the recording maximally) so that the ideas about the class should not be forgotten.

3. The recordings could be stopped any time and they were commented by the pedagogue. This step is critical since analysing recordings has several types:

- According to the first type, having watched the complete recording the participant can freely give an account of any event taking place in the class. This type was not applied as there is a danger that the teacher does not mention certain class activities for some reason.

- It is also possible that the researcher selects the passage to be analysed and by asking questions he tries to explore the pedagogue's thoughts related to the chosen part. Nevertheless, in this case what is happening is not the exploration of the pedagogue's thoughts but instead an analysing process reflecting the researcher's way of thinking. Thus, this technique was not applied either.

- According to the third type the teacher can stop the recording any time and can comment on what they have seen. Even in this case it is possible that the pedagogue would skip some parts he would not want to talk about. 
OF PSYCHOLOGY

IN THE $21^{\text {st }}$ CENTURY Volume 6, 2013

- To overcome the problems mentioned above both parties (the researcher and the teacher) could stop the recording any time. This way the pedagogue could comment on what they have seen and could also answer the emerging questions.

4. The pedagogue commented on and accounted for the activities. The complete conversation was recorded with a dictaphone.

5. The last step involved typing and analysing the recorded material.

\section{Data Analysis}

The analysis of reflective constraints became possible after transforming the audio material of class commentaries into text data. The processing of text corpus was conducted using the software called MAXQDA, Version 10. During the analysis the focus was on the presence of reflective constraints in the discourse as determined by Kimmel (2006) (lack of teacherly characteristics, emotions, lack of knowledge, beliefs and school context); therefore, following deductive logic, the terms "lack of teacherly characteristics", "emotions", "lack of knowledge", "beliefs" and "school context" were recorded as codes in the code list. In the first phase, based upon their content we attached larger text segments to the codes. Then, following inductive logic on the basis of Grounded Theory (Glaser \& Strauss, 1967), we further categorized these text segments into subcodes. The whole process was conducted in order to establish a code hierarchy since this way the subcodes behind the main codes and the pedagogue's related thoughts also became explorable. Thus, data processing was facilitated by the combination of deductive and inductive coding logic.

The reliability of coding was ensured by intracoding (see Dafinoiu \& Lungu, 2003). In three days the text corpus was coded twice, which was followed by the comparison of the results of the two coding procedures. The reliability index of coding was the maximum possible 1.

A significant element of qualitative investigations is applying triangulation (Flick, 2008). Investigator triangulation involves integrating several researchers into the research process in order to minimize the subjective effects originating from the qualitative nature of the investigation. In this case there was no possibility of applying this type (since the research was not executed in a team, but the subjective effects were eliminated by intracoding), but a professional dialogue with the pedagogue about the results was pursued. To ensure theory triangulation a criterion-based theoretical model was outlined, out of which the criteria that best suited to the purpose of the research was used. Methodological triangulation involves using more than one technique to accomplish a qualitative-qualitative or a qualitative-quantitative combination. With this multiple approach the results can fulfil the principle of complementarity, they can complement each other and can contribute to a thorough exploration of the problem (Kelle \& Erzberger, 2002). For this reason to investigate the constraints of reflective thinking cognitive mapping was also applied: once, at the outset of the research the pedagogue made an unstructured cognitive map about the classroom activities (discussing the results of this analysis would extend the scope of this study). The application of the two techniques is justified as they are capable of examining the same problem; furthermore, the visual elements of the map can be traced throughout the stimulated recall. During data triangulation the one-sample investigation made only time differentiation possible because the recordings of the lessons took place on different days, and it took a week to cover the whole process. During the investigation place- and person differentiation was not feasible; however, we did not deal with little or limited amount of information since the stimulated recall and the cognitive map complemented with the researcher's notes provided detailed information about the elements of the pedagogue's activities.

\section{Results of Research}

The reflective constraints defined by Kimmel (2006) are partly shown by the data since only three (lack of knowledge, emotions and school context) of the five constraints stated by him (lack of teacherly characteristics, lack of knowledge, emotions, beliefs and school context) appeared in the text corpus. So these three constitute the main categories of the analysis. The breakdown of the main categories into subcategories was also made in Data Analysis. One subcategory (lesson plan- 
ning) to "lack of knowledge", two subcategories (children and students) to "emotions" and four Volume 6, 2013 subcategories (lack of time, fatique, curriculum and textbook) to "school context" were attached (see Figure 1). Figure 1 presents the network about reflective constraints (code hierarchy) made with MAXQDA MAXMaps.

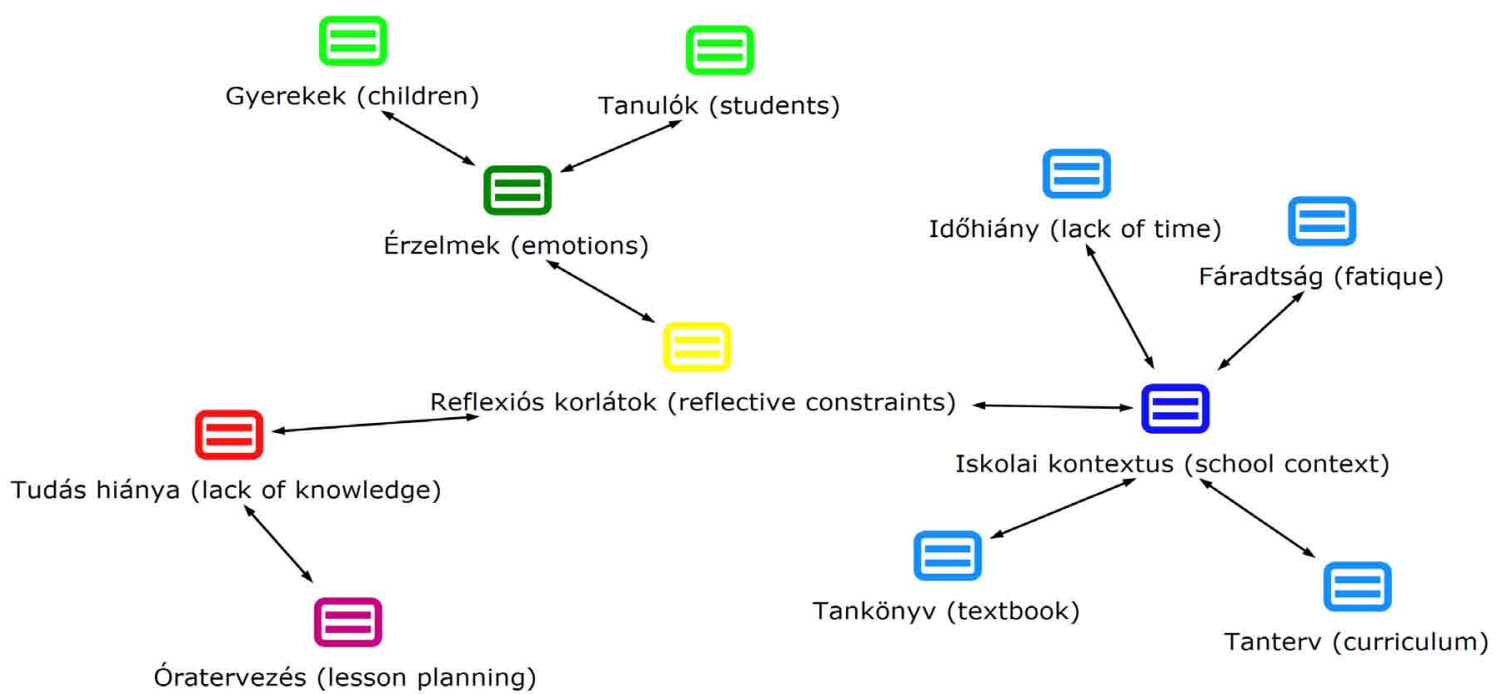

Figure 1: Reflective constraints: main- and subcategories.

The purports of the subcategories mean the new information obtained from the research because they give answers to the question "What is a restrictive factor in the teacher's activity and why" (see Discussion). While examining the constraints of reflective thinking main- and subcategories can consist of different elements regarding different pedagogues since the individual and hidden mechanisms of the teacher's activity can shed light upon different restrictive factors.

\section{Discussion}

\section{Emotions Attached to Teaching as Reflective Constraints}

A reflective dialogue is difficult as teacherly activities have to be discussed with another colleague, the school director or the researcher. Teaching is a personally and emotionally challenging activity that puts the whole personality to the test; hence, the pedagogue suffers from a strong emotional ordeal when reflecting on his own activities (Kimmel, 2006). A basic condition for successful reflection is that the pedagogue has to become "detached" from the class to the extent that he could recall what happened and then, based on his experience, he could re-evaluate his knowledge. The other partner in the dialogue, a staff member, a colleague can play a significant part in this process. When processing the emotional aspects the pedagogue mentioned the students, the children:

\footnotetext{
"There are as many different ideas as children."

"You can see the joy on their faces/.../that's what it is all about."
}

It is clear from the pedagogue's thoughts that institutions and pedagogues emphasizing teacherstudent cooperation, interactivity and an appropriate pedagogical relationship create an atmosphere that is different from classical frontal teaching and learning environment thus offering a different emotional saturation in everyday pedagogy.

\section{Lack of Pedagogical Knowledge as a Reflective Constraint}

There is a strong relationship between reflection and the pedagogue's knowledge as it is justi- 
OF PSYCHOLOGY

IN THE $21^{\text {st }}$ CENTURY Volume 6, 2013

52

fied by the study written by Falus (2001). Stimulated recall may shed light on how the lack of his pedagogical knowledge can influence the extent to which he can reflect on his own activities and the quality of the reflection.

It is an interesting question how pedagogues should learn the techniques of reflection. This process becomes feasible if they rely on their own experience since this way they can describe the complicated phases of the teaching process and they can get a complete picture of the knowledge types and ideas determining their activities. In the process of reflectivity the reflections given by the colleagues should have an outstanding role as the dialogues held among them and the analysis of lessons help to develop reflective thinking (Szivák, 2003). The pedagogue in the present research reflected on problems related to lesson planning: he had conceptual, terminology- and performancerelated difficulties:

"Informal lesson planning /.../ may not be acceptable from a methodological viewpoint; I still cannot decide after being into teaching for 9 years."

Lack of knowledge as a reflective constraint shows a complex picture of the activities since not only the answers to the question of "what", but also the answers to the questions of "how" and the "how do I know" can appear, which refer to the presence of a higher level of reflective thinking.

\section{School Context as a Reflective Constraint}

School context as a reflective constraint can be traced back to several factors according to the pedagogue's thoughts. The factors mentioned by the pedagogue can be found in the summary written by Kimmel (2006) however, they do not touch upon an essential viewpoint (mentioned by Schön, 1983) emphasizing the necessity of the acquisition of a common professional terminology which is relevant to give and get reflections. School context is the field where the pedagogue presented the highest number of constraints as he reflected on four elements: teacherly fatigue, lack of time, the curriculum and the textbook:

- Teacherly fatigue:

"You need to be attentive very much /... / when you are /... / so tired that you just cannot walk through the desks or that you cannot get information directly from their exercise books."

- Lack of time:

"If I want to know what the student knows I am testing him/her orally for an awfully long time, this /... / is a waste of time."

"I have more serious time management problems than other colleagues."

"I would have liked to get them to do more tasks / . . / I didn't manage /... / you cannot run after shadows."

- Curriculum:

"Anything that makes them think is worth it, but you can't get carried away. You need to think it over that a curriculum has to be completed."

- Textbook:

"Although they are not in fashion any more I like textbooks that are full of tasks, /... / which make children acquire a line of thinking step by step and basically make them work on their own."

"The textbook is not suitable for individual work / ... / the wording of the text is so precise that students because of their existing deficiencies don't even understand them."

Having looked at the constraints presented by the pedagogue it can be seen clearly that subjective effects also play a part, which makes the creation of a suitable school context complicated (but not impossible). 


\section{Conclusion}

The results justified the hypothesis that developing reflective thinking does contribute to making teaching activities more effective. The connection between reflection and the effectiveness of the pedagogue's activity is evident since the pedagogue while reflecting could see the teaching process more and more complex. In spite of the fact that the teacher tried to widen the range of reflection with alloying theoretical knowledge and practical work he had to come up against constraints in this process. The realization of the revealed constraints can stimulate and encourage the teacher to make the teaching activity more effective. On the basis of the reflections the relationships between a pedagogue's thoughts and activities could also be discovered; furthermore, the reflections may facilitate a more differentiated pedagogical knowledge on behalf of the teachers.

The participant handled the situations on the basis of how differentiated his ideas and his pedagogical knowledge were, he acted making use of his teaching practice and he reflected on his activities by looking for cause-and-effect relationships in most content areas. His way of thinking is complex but can be followed easily. He watched the recordings with interest and reflected on his activities with care considering several aspects. Stimulated recall is applicable to explore teacherly behaviour, activities and the inner, hidden, context-dependent thought processes determining the given situation; thus, the qualitative method contributed to the exploration of reflective attitude.

\section{References}

Atkinson, T., \& Claxton, G. (Eds.). (2000). The Intuitive Practitioner. On the value of not always knowing what one is doing. Buckingham: Open University Press.

Falus, I. (2001). A gyakorlat pedagógiája. (The Pedagogy of Practice). In Golnhofer, E. \& Nahalka, I. (Eds), A pedagógusok pedagógiája. (The Pedagogy of Pedagogues) (pp. 15-26). Budapest: Nemzeti Tankönyvkiadó.

Falus, I., \& Kimmel, M. (2003). A portfólió. (The Portfolio). Budapest: Gondolat Kiadói Kör, Books in Print.

Dafinoiu, I., \& Lungu, O. (2003). Research Methods in the Social Sciences / Metode de cercetare în ştiințele sociale. Frankfurt am Main: PeterLang, Europäischer Verlag der Wissenschaften.

Dewey, J. (1933). How We Think. Boston: D. C. Heath.

Flick, U. (2008). Triangulation. Eine Einführung. Wiesbaden: VS Verlag.

Glaser, B. G., \& Strauss, A. L. (1967). The Discovery of Grounded Theory: Strategies for Qualitative Research. Chicago: ABC.

Kelle, U., \& Erzberger, C. (2002). Qualitative und quantitative Methoden: kein Gegensatz. In Flick, U., von Kardorff, E., \& Steinke, I. (Hrsg.), Qualitative Forschung. Ein Handbuch (pp. 299-309). Hamburg: Rowohlt Verlag.

Kimmel, M. (2006). A tanári reflexió korlátai (The Limitations of Teacherly Reflection). Pedagógusképzés, 3-4, 35-49.

Korthagen, F.A.J. (2004). In search of the essence of a good teacher: towards a more holistic approach in teacher education. Teaching and Teacher Education, 1, 77-97.

Jank, W., \& Meyer, H. (2002). Didaktische Modelle. Berlin: Cornelsen Scriptor.

Lohmann, G. (2003). Mit Schülern klarkommen. Professioneller Umgang mit Unterrichtsstörungen und Disziplinkonflikten. Berlin: Cornelsen Scriptor.

Richardson, V. (1996). The Role of Attitudes and Beliefs in Learning to Teach. In Sikula, J. (Eds), Handbook of Research on Teacher Education (pp. 102-119). New York: MacMillan.

Sántha, K. (2007). Kvalitatív módszerek alkalmazása a reflektív gondolkodás feltárásában (Qualitative Methods in Exploring Reflective Thinking). In Falus, I. (Eds), A tanárrá válás folyamata (The Process of Becoming a Teacher) (pp. 177-243). Budapest: Gondolat Kiadó. 
54 Schön, D. (1983). The Reflective Practitioner. How Professionals Think in Action. London: Temple Smith.

Schön, D. (1987). Educating the Reflective Practitioner. San Francisco: Jossey-Bass.

Schratz, M. (1998). Unterrichtforschung. Fernuniversität in Hagen. Hagen: Fachbereich Kultur- und Sozialwissenschaften.

Szivák, J. (2003). A reflektív gondolkodás fejlesztése (Developing Reflective Thinking). Budapest: Gondolat Kiadói Kör, Books in Print.

Advised by Zoltan Kiszely, Kodolányi János University of Applied Sciences, Hungary

Received: April 19, 2013

Accepted: May 30, 2013

Kálmán Sántha $\quad \mathrm{PhD}$, College Professor, Department of Educational Science, Kodolányi János University of Applied Sciences, Fürdő 1., 8000, Székesfehérvár, Hungary.

E-mail: skalman@uranos.kodolanyi.hu

Website: http://www.kodolanyi.hu 